\title{
MADZHAB HUKUM ISLAM
}

\author{
Oleh: \\ Sheila Fakhria ${ }^{*}$
}

\begin{abstract}
The school of law are determined by law and the period of time so that by jurists make legal interpretation based on the time and place. So at this time jurists are always reviewing the law that is based on the presence or emergence of various schools in the philosophy of law shows the struggle of ideas will not cease in the field of law. Similarly, the existence of Islamic law in a society that seeks to be grouped according typology of existing law schools in the philosophy of law.
\end{abstract}

\section{Kata Kunci : Madzhab Hukum Islam}

\section{Pendahuluan}

Secara historis zaman terus berkembang melalui hierarkis perkembangan yang terus diiringi dengan perubahan sosial, dimana dua hal ini akan selalu beriringan. Keberadaan manusia yang dasar pertamanya bebas menjadi hal yang problematik ketika ia hidup di dalam komunitas sosial. Kemerdekaan ini akan berbenturan dengan kemerdekaan individu lainnya bahkan dengan makhluk yang lain. Maka muncullah tata aturan, norma, nilai-nilai yang menjadi kesepakatan universal yang ditaati. Di sinilah hukum muncul dalam peradaban manusia untuk menjunjung tingi nilai-nilai kemanusiaan. Kemudian ketika hukum itu diberi jawaban atau tanggapan berbeda-beda oleh para akademisi kemudian diikuti oleh masyarakatnya, maka dari sinilah akan muncul aliran-aliran dalam hukum itu sendiri.

Oleh karena itu, makalah ini akam menguraikan tentang aliran-aliran hukum yang berkembang pada peradaban manusia. Dalam hal ini penulis membatasi pembagian aliran hukum pada

\footnotetext{
Mahasiswa Pascasarjana UIN Sunan Kalijaga. E-maile: shelafakhria@gmail.com

Volume 26 Nomor 1 Januari 2015 
enam pembagian, diantaranya mazhab hukum alam, mazhab hukum positif/positivism hukum, mzhab hukum murni, mazhab sosisological jurisprudence, dan mazhab realism hukum.

\section{Madzhab- madzhab Hukum}

Adanya aliran hukum adalah ditentukan oleh masa dan waktu yang sehingga oleh para ahli hukum membuat penafsiran hukum berdasarkan waktu dan tempat. Sehingga pada saat ini para ahli hukum selalu mengkaji hukum itu berdasarkan dengan adanya atau timbulnya berbagai aliran dalam filsafat hukum menunjukan pergulatan pemikiran yang tidak henti-hentinya dalam lapangan ilmu hukum. Apabila pada masa lalu, filsafat hukum merupakan produk sampingan dari para filsuf, dewasa ini kedudukannya tidak lagi demikian karena masalah-masalah filsafat hukum telah menjadi bahan kajian tersendiri bagi para ahli hukum.

Dalam kajian filsafat hukum, dikenal beberapa aliran tentang hukum diantaranya: (a) Aliran hukum alam; (b) Aliran hukum positif; (c) Aliran hukum murni; (d) Madzhab sejarah; (e) Aliran sosiological jurisprudence; (f) Aliran Realisme hukum. Aliran-aliran dimaksud, diuraikan sebagai berikut.

\section{Madzhab Hukum Alam}

Hukum alam adalah hukum yang digambarkan belaku abadi sebagai hukum yang norma-normanya berasal dari Tuhan Yang Maha Adil, dari alam semesta dan dari akal budi manusia, sebagai hukum yang kekal dan abadi yang tidak terikat oleh waktu dan tempat sebagai hukum yang menyalurkan kebenaran dan keadilan dalam tingkatan smutlak-mutlaknya kepada segenap umat manusia. ${ }^{1}$ Para pemikir terdahulu, umumnya menerima suatu hukum yaitu hukum alam atau hukum kodrat. Berbeda dengan hukum positif sebagaimana diterima oleh orang dewasa ini, hukum alam yang diterima sebagai hukum tersebut bersifat tidak tertulis. Hukum alam ditanggapi tiap-tiap orang sebagai hukum oleh sebab menyatakan apa yang termasuk alam

${ }^{1}$ Lili Rasyidi , Filsafat Hukum, Mazhab dan Refleksinya, (Bandung: Remaja Rosdakarya, 1994), hlm 17. 
Madzhab Hukum... Oleh: Sheila Fakhria

manusia sendiri yaitu kodratnya. ${ }^{2}$ Madzhab ini dikembangkan oleh beberapa pakar yang ada di zaman Yunani dan Romawi.

\section{Madzhab Hukum Alam di Zaman Yunani}

Orang Yunani pada mulanya (abad ke-5) masih bersifat primitive, yaitu hukum dipandang sebagai suatu keharusan alamiah (nomos); baik semesta alam maupun hidup semesta alam maupun hidup manusia. Namun pada abad ke -4 SM para filsuf mulai insaf tentang peran manusia dalam mebentuk hukum, misalnya Socrates. Socrates menuntut supaya para penegak hukum mengindahkan keadilan sebagai nilai yang melebihi manusia. Demikian juga pendapat Plato (427-347 SM) dan Aristoteles (348-322 SM) yang mulai memepertimbangkan bahwa manakah aturan yang lebih adil yang harus menjadi alat untuk mencapi tujuan hukum, walaupun mereka juga tetap mau tunduk pada tuntutantuntutan alam sehingga zaman ini dikenal dengan zaman atau aliran hukum alam. ${ }^{3}$

\section{Mazhab Hukum Alam di Romawi}

Mazhan hukum alam dalam pemikiran di zaman Romawi dimunculkan oleh pemikir-pemikir yang dipengaruhi oleh pikiran-pikiran yang berkembang di Yunani terutama oleh pikiran Socrates, Plato dan Aristoteles. Salah satu tokoh romawi yang banyak mengemukakan pemikirannya tentang hukum alam adalah Cicero, seorang yuris dan negarawan. Cicero (105-43 BC) mengajarkan konsepnya tentang a true law (hukum yang benar) yang disesuaikannya dengan right reason, serta sesuai dengan alam dan menyebar di antara manusia dan sifatnya immutable dan eternal. Hukum apapun harus bersumber dari true law itu. Tokoh lain adalah Gaius yang membedakan antara ius civile dan ius gentium. Ius civile adalah hukum yang bersifat khusus pada suatu negara tertentu, sedangkan

\footnotetext{
${ }^{2}$ Huijbers, 1995, hlm 82.

${ }^{3}$ Zainuddin Ali, Filsafat Hukum, (Jakarta: Sinar Grafika, 2006), hlm 47-48.
} 
ius gentium adalah hukum yang berlaku universal yang bersumber pada akal pemikiran manusia. ${ }^{4}$

Kedua zaman itu, Yunani dan Romawi mempunyai perbedaan konkret mengenai pandangan terhadap hukum. Menurut pendapat Achmad Ali, pemikiran Yunani lebih bersifat teoretis dan filosofis, sedangkan pemikiran Romawi lebih menitikberatkan pada hal-hal yang praktis dan berkaitan dengan hukum positif. ${ }^{5}$

Hukum alam sesungguhnya merupakan sebuah konsep yang mencakup banyak teori di dalamnya. Bernagai anggapan dan pendapat yang dikelompokkan ke dalam hukum alam bermunculan dari masa ke masa. Pada suatu saat hukum alam muncul dengan kuatnya, pada saat lain diabaikan, tetapi yang pasti hukum alam tidak pernah mati. Hukum Alam adalah hukum yang normanya berasal dari Tuhan Yang Maha Esa, dari alam semesta dan dari akal budi manusia, karena ia digambarkan sebagai hukum yang berlaku abadi. ${ }^{6}$

4. Madzhab Hukum Positif/ Positivisme Hukum

Mazhab hukum positif menurut Hans Kelsen yang diikuti Lili Rasyidi merupakan suatu teori tentang hukum yang senyatanya dan tidak mempersoalkan senyatanya itu, yakni apakah senyatanya itu adil atau tidak adil. Selain itu, dapat dikatakan bahwa hukum positif merupakan kebalikan dari hukum alam. Sebab, mazhab ini mengidentikkan hukum dengan undang-undang. Satu-satunya sumber hukum adalah undang-undang. ${ }^{7}$

\footnotetext{
${ }^{4}$ Zainuddin Ali, Filsafat Hukum, (Jakarta: Sinar Grafika, 2006), hlm
}

49

${ }^{5}$ Ibid.

${ }^{6}$ Otje Salman, Filsafat Hukum: Perkembangan dan Dinamika

Masalah, (Bandung :Refika Aditama), 2010, hlm 63.

7 Zainuddin Ali, Filsafat Hukum, (Jakarta: Sinar Grafika, 2006), hlm 54 
Positivisme hukum ada dua bentuk, yaitu positivisme yuridis dan postivisme sosiologis. Adapun uraiannya adalah sebagai berikut: ${ }^{8}$

a. Positivisme Yuridis

Dalam perspektif positivisme yuridis, hukum dipandang sebagi suatu gejala tersendiri yang perlu diolah secara ilmiah. Tujuan positivisme yuridis adalah pembentukan struktur rasional system yuridis yang berlaku. Dalam praksisnya konsep ini menurunkan suatu teori pembentukan hukum bersifat professional yaitu hukum merupakan ciptaan para ahli hukum. Prinsipprinsip positivisme yuridis adalah :

i. Hukum adalah sama dengan undang-undang.

ii. Tidak ada hubungan mutlak antara hukum dan moral. Hukum adalah ciptaan para ahli hukum belaka

iii. Hukum adalah suatu closed logical system, untuk menafsirkan hukum tidak perlu bimbingan norma sosial, politik dan moral cukup disimpulkan dari undang-undang. Tokohnya adalah R. von Jhering dan John Austin.

b. Positivisme sosiologis

Dalam perspektif positivisme sosiologis, hukum dipandang sebagai bagian dari kehidupan masyarakat. Dengan demikian hukum bersifat terbuka bagi kehidupan masyarakat. Keterbukaan tersebut menurut positivisme sosiologis harus diselidiki melalui metode ilmiah. Tokohnya adalah Augus Comte yang menciptakan ilmu pengetahuan baru yaitu, sosiologi.

Mazhab yang juga dikenal sebagai aliran hukum positif memandang perlu secara tegas memisahkan antara hukum dan moral, yakni antara hukum yang berlaku dan hukum yang seharusnya, antara das sein dan das sollen. Sebelum aliran ini lahir, terlebih dulu telah berkembang suatu pemikiran dalam ilmu hukum yang disebut sebagai

\footnotetext{
${ }^{8}$ Abdul Ghofur Anshori, Filsafat Hukum, (Yogyaarta: Gajah Mada University Press, 2009), hlm 94-95.
} 
Legisme, yakni faham yang memandang tidak ada hukum di luar undang-undang, atau satu-satunya sumber hukum adalah undang-undang. ${ }^{9}$ yaitu: ${ }^{10}$

Positivisme hukum dibedakan dalam dua corak,

a. Aliran Hukum Positif Analistis.

Sarjana yang membahas secara komprehensif system positivisme hukum analitik adalah John Austin, seorang yuris Inggris. Austin mendefinisikan hukum sebagai suatu aturan yang ditentukan untuk membimbing mahluk berakal oleh makhluk berakal yang telah memiliki kekuatan mengalahkannya. Sehingga karenanya hukum, yang dipisahkan dari keadilan dan sebagai gantinya didasarkan pada ide baik dan buruk, dilandaskan pada kekuasaan yang tertinggi.

Semua hukum positif berasal dari pembuat hukum yang sangat menentukan, sebagai yang berdaulat. Austin mendefinisikan penguasa sebagai seorang manusia superiori yang menentukan, bukan dalam kebiasaan ketaatan dari suatu masyarakat tertentu. Ia menjelaskn bahwa atasan itu mungkin seorang invidu, sebuah lembaga, atau sekumpulan individu. Karakteristik hukum yang terpenting menurut teori Austin terletak pada karakter imperatifnya. Hukum dipahami sebagai suatu perintah dari penguasa.

Menurut John Austin (1790-1859) hukum dibedakan menjadi dua hal, yaitu: ${ }^{11}$

i. Hukum yang diciptakan oleh Tuhan untuk manusia.

ii. Hukum yang disusun dan dibuat oleh manusia, yang terdiri dari:

> Hukum dalam arti yang sebenarnya. Jenis ini disebut sebagai hukum positif yang terdiri dari

9 Ahmad Syauqi, Aliran-Aliran Dalam Filsafat Hukum Dan Yang Relevan Dengan Suasana Kebangsaan Indonesia, pdf.

${ }^{10}$ Fathurrahman Djamil, Filsafat Hukum Islam, (Jakarta: Logos Wacana Ilmu, 1997), hlm 56-62.

${ }^{11}$ Abdul Ghofur Anshori, Filsafat Hukum, hlm 95. 
hukum yang dibuat penguasa, seperti: undangundang, peraturan pemerintah, dan sebagainya, hukum yang dibuat atau disusun rakyat secara individuil yang dipergunakan untuk melaksanakan hak-haknya, contoh hak wali terhadap perwaliannya. Dalam konteks ini Austin membagi hukum ke dalam empat unsur, meliputi; perintah (command), sanksi (sanction), kewajiban (duty), dan kedaulatan (sovereignty). Sehingga ketentuan yang tidak memenuhi keempat unsur tersebut tidak dapat dikatakan sebagai hukum.

Hukum dalam arti yang tidak sebenarnya, dalam arti hukum yang tidak memenuhi persyaratan sebagai hukum, contoh: ketentuan-ketentuan dalam organisasi atau perkumpulanperkumpulan.

b. Positivisme Pragmatik

Sebagai lawan dari teori Austin adalah gerakan kaum Realis Amerika yang disebut Positisme Pragmatis, yang mempelajari hukum sebagai karya-karya dan fungsinya bukan sebagai yang tertulis di atas kertas. Hal ini merupakan suatu pendekatan pragmatis terhadap hukum yang mengarah pada akhir segala sesuatu hasil dari akibat-akibatnya. Inti dari pendekatan ini pada problema-problema hukum adalah tidak mengikuti apa yang tercatat di dalam kertas. Hal ini masih sangat bersifat umum, oleh karenanya untuk mengkonkritkan apa yang ada dalam pikiran para realis berbalik pada ilmuilmu pengetahuan yang mulai mengamati perilaku manusia dalam masyarakat terutama ekonomi, kriminologi, sosiologi umum dan psikologi. ${ }^{12}$

Hukum menurut Postivisme Pragmatik, harus ditentukan oleh fakta-fakta sosial yang berarti sebuah konsepsi hukum dalam perubahan terus-menerus dan konsep masyarakat yang berubah lebih cepat

${ }^{12}$ Fathurrahman Djamil, Filsafat Hukum Islam, hlm 61. 
dibandingkan hukum. Kaum Positivisme Pragmatis mementingkan hukum seharusnya sedangkan teori Austin hanya mementingkan apa hukum itu.

5. Mazhab Hukum Murni

Pembahasan utama Hans Kelsen (lahir 1881) dalam teori hukum murni adalah untuk membebaskan ilmu hukum dari unsure ideologis. Teori hukum murni menurut Kelsen adalah sebuah teori hukum positif. Teori ini berusaha menjawab pertanyaan "apa hukum itu?" tetapi bukan pertanyaan "apa hukum itu seharusnya?". Teori ini berusaha mengkonsentrasikan diri pada hukum semata-mata dan berusaha melepaskan ilmu pengetauan hukum dari campur tangan ilmu pengetahuan asing seperti psikologi dan etika. Kelsen memisahkan pengertian hukum dari segala unsur yang berperan dalam pembentukan hukum seperti psikologi, sosiologi, sejarah politik dan bahkan juga etika. Pengertian hukum menyatakan hukum dalam arti formalnya yaitu sebagai peraturan yang berlaku secara yuridis. Inilah hukum yang murni (das raine recht). ${ }^{13}$

Teori murni tentang hukum adalah ilmu normative tentang masyarakat. Oleh karena itu, ilmu hukum harus dibedakan secara jelas dari politik hukum. Ilmu hukum adalah usaha untuk memperoleh pengetahuan tentang hukum positif yang ada, menganalisis strukturnya, menetapkan definisi dari pengertian yang digunakan hukum positif. Selain itu, teori hukum murni adalah tentang hukum tidak mempermasalakan pengertian keadilan. Sebagai ajaran tentang hukum positif, teori murni tentang hukum adalah teori tentang hukum senyatanya tanpa mempermasalahkan yang senyatanya itu, yakni apakah hukum positif yang ada itu baik atau bauruk, adil atau tidak adil. ${ }^{14}$

Selanjutnya hukum menurut Kelsen dan Austin merupakan sebuah tatanan yang digaransi oleh ancamanancaman, ia mengabaikan fungsi utama hukum sebagai alat

${ }^{13}$ Abdul Ghofur Anshori, Filsafat Hukum, hlm 98-99.

${ }^{14}$ Lili Rasyidi, Filsafat Hukum, Mazhab dan Refleksinya...., hlm 60- 
kontrol sosial di luar proses pengadilan atau penuntutan perdata. Maka menurut Hans Kelsen dalam hukum terdapat suatu norma dasar yang harus dianggap sebagai sumber keharusan di bidang hukum. Norma dasar (grandnorm) tersebut berbunyi: "Orang-orang harus menyesuaikan dirinya dengan apa yang telah ditentukan". ${ }^{15}$

Inti ajaran Hans Kelsen menurut Friedman, seperti yang ditulis oleh Teguh Prasetyo dan Abdul Halim Barkatullah adalah: Pertama, tujuan teori hukum seperti halnya setiap ilmu, adalah untuk mengurangi kekalutan serta meningkatkan kesatuan; Kedua, teori hukum adalah ilmu, dan bukan kehendak. Ia adalah pengetahuan tentang hukum yang ada, dan bukan tentang hukum yang seharusnya ada; Ketiga, ilmu hukum adalah normative, dan bukan ilmu alam; Keempat, teori hukum sebagai teori tentang norma-norma, tidak berurusan dengan persoalan efektivitas norma-norma hukum; Kelima, suatu teori tentang hukum sifatnya formal, merupakan suatu teori tentang cara pengaturan dan isi yang berubah-ubah menurut jalan atau pola yang spesifik; Keenam, hubungan antara teori hukum dengan suatu sistem hukum positif tertentu adalah sama halnya dengan hubungan antara hukum yang mungkin dan hukum yang ada. ${ }^{16}$

6. Mazhab Sejarah

Lahirnya mazhab sejarah merupakan suatu reaksi yang langsung terhadap suatu pendapat yang diketengahkan oleh Thibaut dalam pamfletnya yang berbunyi : Uber Die Notwendig-keit Eines Allgemeinen Burgerlichen Rechts fur Deutschland (Keperluan akan adanya kodifikasi hukum perdata bagi negeri Jerman). Ahli hukum perdata Jerman ini menghendaki akan agar di Jerman diperlukan kodifikasi perdata dengan dasar hukum Prancis. Sebagaimana diketahui bahwa ketika Prancis meninggalkan Jerman muncul masalah hukum apa yang hendak diperlukan di negeri ini. Juga, merupakan suatu reaksi yang tidak langsung terhadap aliran

\footnotetext{
${ }^{15}$ Zainuddin Ali, Filsafat Hukum......, hlm 103.

16 Prasetyo, Teguh dan Barkatullah, Abdul Halim., Ilmu Hukum dan Filsafat Hukum, (Yogyakarta: Pustaka Pelajar, 2011), hlm. 107-108. 
hukum alam dan aliran positif tentang hukum intinya mengajarkan bahwa hukum itu tidak dibuat tetapi tumbuh dan berkembang bersama masyarakat. ${ }^{17}$

Aliran ini adalah yang paling terkenal, terutama di negara-negara penganut sistem common law. Tokoh-tokoh penting Mazhab Sejarah, yaitu; Friedrich Karl von savigny (1770-1861), Puchta (1798-1846), dan Henry Summer Maine (1822-1888). Von Savigny menyatakan bahwa hukum timbul bukan karena perintah penguasa atau karena kebiasaan, tetapi karena perasaan keadilan yang terletak dalam jiwa bangsa itu (volkgeist). Adapun Puchta nyaris sama pandangannya dengan Savigny. Ia berpendapat bahwa hukum suatu bangsa terikat pada jiwa bangsa yang bersangkutan. Sedangkan Maine menyatakan ia melakukan penelitian untuk memperkuat pemikiran Von Savigny, yang membuktikan adanya pola evolusi pada pembagi masyarakat dalam situasi sejarah yang sama. ${ }^{18}$

Latar belakang pendapat Savigny di atas timbul karena keyakinannya bahwa dunia terdiri dari bermacammacam bangsa yang mempunyai volgeist (jiwa rakyat) yang berbeda-beda yang tampak dari perbedaan kebudayaan. Ekspresi itu juga tampak pada hukum yang sudah barang tentu berbeda pula pada setiap tempat dan waktu. Isi hukum yang bersumber dari jiwa rakyat itu itentukan oleh pergaulan hidup manusia dari masa ke masa (sejarah).

Hukum, menurut pendapat Savigny, berkembang dari suatu masyarakat yang sederhana yang pencerminannya tampak dalam tingkah laku semua individu kepada masyarakat yang modern dan kompleks dimana kesadaran hukum rakyat itu tampak pada apa yang diucapkan oleh para ahli hukumnya. Inti dari pemikiran mazhab sejarah yang dapat diketahui melalui buku Savigny yang termashur Von

17 Zainuddin Ali, Filsafat Hukum, hlm 59. Lihat juga Otje Salman, Filsafat Hukum: Perkembangan dan Dinamika Masalah, (Bandung :Refika Aditama, 2010), hlm 70.

${ }^{18}$ Ahmad Syauqi, Aliran-Aliran Dalam Filsafat Hukum Dan Yang Relevan Dengan Suasana Kebangsaan Indonesia, pdf. 
Beruf Unserer Zeit fur Gezetsgebug und rechtswissenschaft (tentang tugas zaman kita bagi pembentuk undang-undang dan ilmu hukum), pada prinsipnya merupakan madzhab yang ingin melihat keterkaitan antara hukum dan masyarakat. Dalam arti bahwa, aliran ini menolak hukum itu dibuat oleh penguasa atau pemerintah. ${ }^{19}$

7. Madzhab Sosiological Jurisprudence

Mazhab sociological Jurisprudence dipelopori oleh Roesco Pound, Eugen Ehrlich, Benyamin Cardozo, Kantorowich, Gurvitch dan lain lain. Inti pemikiran madzhab ini menganggap bahwa hukum yang baik adalah hukum yang sesuai dengan hukum yang ada dalam masyarakat. Pemikiran ini berkembang di Indonesia dan Amerika.

Kata yang sesuai pada uraian di atas, mencerminkan nilai-nilai yang berkembang di dalam masyarakat. Mazhab ini berbeda dengan aliran sosiologi hukum. Sosiologi hukum tumbuh dan berkembang di Eropa Kontinental. Sebagaimana yang dijelaskan oleh Roscoe Pound mengenai perbedaan sociological Jurisprudence dan sosiologi hukum, yaitu bahwa sociological Jurisprudence merupakan suatu madzhab dalam filsafat hukum yang memepelajari hubungan timbal balik antara hukum dan masyarakat, sosiologi hukum adalah cabang sosiologi yang mempelajari pengaruh masyarakat kepada hukum. Singkatnya, sociological jurisprudence mempunyai cara pendekatan yang bermula dari hukum ke masyarakat sedangkan sosiologi hukum sebaliknya, yaitu pendekatannya dari masyarakat ke hukum. ${ }^{20}$

Madzhab ini mempunyai ajaran mengenai pentingnya living law (hukum yang hidup dalam masyarakat). Namun, mazhab ini lahir dari anti these positivisme hukum. Karena sociological jurisprudence menganut paham bahwa hanya hukum yang mampu menghadapi ujian akal akan hidup terus. Hukum adalah pengalaman yang diatur dan dikembangkan

${ }^{19}$ Zainuddin Ali, Filsafat Hukum, hlm 60.

${ }^{20}$ Lili rasyidi, Filsafat Hukum, Mazhab dan Refleksinya, (Bandung:

Remaja Rosdakarya, 1994), hlm 84. 
oleh akal, yang diumumkan dengan wibawa oleh badanbadan yang membuat undang-undang atau mengesahkan undang-undang dalam masyarakat yang berorganisasi politik dan dibantu oleh kekuasaan masyarakat itu. Aliran ini tampak jelas memisahkan secara tegas antara hukum positif (hukum adalah undang-undang yang dibuat negara) dan hukum yang hidup (hukum adalah norma-norma yang hidup dan diakui oleh masyarakat).

Menurut Ehrlich pusat gaya tarik pengembangan hukum tidak terletak pada perundang-undangan, ilmu hukum, tetapi pada masyarakat sendiri. Ajaran berpokok pada pembedaan hukum positif dengan hukum yang hidup atau dengan kata lain pembedaan kaidah-kaidah hukum dengan kaidah sosial lainnya. Hukum positif hanya akan efektif apabila selaras dengan hukum yang hidup dalam masyarakat. $^{21}$

8. Madzhab Realisme Hukum

Aliran realisme hukum merupakan salah satu subaliran dari positivisme hukum yang dipelopori oleh John Chipman, Gray, Oliver Wendel Holmes, Karl Liwellyn, Jerome Frank, William James dan lain-lain. Menurut Llwellyn, realisme hukum bukanlah merupakan aliran di dalam filsafat hukum, melaikan sebuah gerakan dalam cara berpikir tentang hukum. ${ }^{22}$

Dalam pandangan penganut Realisme, hukum adalah hasil dari kekuatan-kekuatan sosial dan konstrol sosial. Beberapa ciri utama realisme diantaranya: ${ }^{23}$

a. Tidak ada mazhab realis. Realisme adalah gerakan dari pemikiran dan cara kerja hukum,

b. Realisme adalah konsepsi hukum yang terus berubah dan alat untuk tujuan-tujuan sosial, sehingga tiap bagian hrus diuji tujuan dan akibatnya,

21 Otje Salman, Filsafat Hukum: Perkembangan dan Dinamika Masalah, (Bandung :Refika Aditama), 2010, hlm 72.

${ }_{22}$ Zainuddin Ali, Filsafat Hukum....., hlm 63.

${ }^{23}$ Fathurrahman Djamil, Filsafat Hukum Islam...., hlm 61. 
c. Realisme menganggap adanya pemisahan sementara antara hukum yang ada dan harusnya ada, untuk tujuantujuan studi,

d. Realisme tidak percaya pada ketentuan-ketentuan dan konsepsi-konsepsi hukum, selama ketentuan-ketentuan dan konsepsi hukum menggambarkan apa yang sebebarnya dilakukan oleh pengadilan-pengadilan dan orang-orang,

e. Realisme menekankan evolusi tiap bagian hukum dengan mengingatkan akibatnya.

Lebih jauh Llwellyn berpendapat bahwa hukum harus diterima sebagai sesuatu yang terus-menerus berubah, hukum bukan sesuatu yang statis. Tujuan hukum harus senantiasa dikaitkan dengan tujuan masyarakat di mana hukum itu berada. Masyarakat merupakan proses yang terus-menerus berubah secara berkesinambungan, oleh karena itu perubahan hukum pun merupakan suatu yang esensial. Demikian pula ternyata bahwa dibutuhkan penekanan pada evaluasi hukum terhadap dampak dan efek pada masyarakat. ${ }^{24}$

Dari pandangan yang dikemukakan oleh Llwellyn di atas, Oliver Wendels Holmes mengemukakakn bahwa hukum adalah apa yang diramalkan akan diputus kenyataannya di pengadilan. Jadi bagi Holmes, hukum adalah kelakuan actual para hakim (patterns of behavior). Sebab, patterns of behavior hakim ditentukan oleh tiga faktor:

a. Kaidah kaidah hukum yang dikonkretkan oleh hakim dengan metode interpretasi dan konstruksi

b. Moral hidup pribadi hakim

c. Kepentingan Sosial ${ }^{25}$

\section{Hukum Islam dalam Mazhab Hukum}

Alam semesta ini bekerja menurut hukumnya sendiri yang bersumber pada hukum Tuhan, oleh karena itu alam bersifat otonom. Tetapi ia tidak bersifat otokratis karena di dalamnya tidak ada jaminan terhadap eksistensinya sendiri dan

\footnotetext{
${ }^{24}$ Zainuddin Ali, Filsafat Hukum...., hlm 64

${ }^{25} \mathrm{Ibid}$, hlm 64
} 
karena ia tidak dapat menerangkan dirinya sendiri juga tidak dapat menerangkan dirinya sendiri. Alam terjalin dengan sempurna dan bekerja sesuai dengan hukum yang Allah kepadanya, maka jelas sekali ada hukum sebab-akibat yang alamiah. Al-Qur'an mengakui adanya hukum sebab akibat yang alamiah, akan tetapi hal ini tidak berarti bahwa setelah menciptakan alam semesta Tuhan lantas tidur. Tuhan yang di dalam kelimpahan kasih-Nya menciptakan alam dan manusia telah memberikan kepada manusia kesadaran dan kemauan untuk memperoleh pengetahuan dan memanfaatkan pengetahuan tersebut untuk menyadari tujuan hidup sesungguhnya. ${ }^{26}$

Al-Qur'an tidak hanya bersifat deskriptif, namun terutama sekali al-Qur'an bersifat preskriptif (memberikan ketentuan-ketentuan). Baik kandungannya maupun kekuatan bentuk penyajiannya tidak hanya dimaksudkan sebagai seruan "seruan" kepada manusia, di dalam pengertian yang biasa unt uk mengubah tingkah laku mereka. Jadi, impas psikologis dan moral dari pernyataan al-Qur'an mempunyai peranan yang penting. Kalimat seperti "Allah telah menutup hati mereka, membutakan mata mereka, dan menutup telinga dari kebenaran", di dalam al-Qur'an memang mempunyai arti deskriptif sesuai dengan proses-proses psikologi bahwa jika manusia sekali melakukan kebaikan atau kejahatan maka kesempatannya untuk mengulangi perbuatan yang serupa semakin bertambah dan untuk melakukan perbuatan sebaliknya akan semaik berkurang. Akan tetapi, yang terpenting adalah kalimat tersebut mempunyai sebuah maksud atau tujuan psikologis yang tertentu yaitu untuk memberikan arah yang benar kepada manusia. ${ }^{27}$

Tidak dapat diragukan lagu bahwa tujuan utama alQur'an adalah menegakkan tatanan masyarakat yang adil, berdasarkan etika dan dapat bertahan di muka bumi ini. Bahwa tujuan al-Qur'an adalah menegakkan sebuah tata masyarakat

\footnotetext{
${ }^{26}$ Fazlur Rahman, Tema Pokok Al-Qur'an, (Bandung: Pustaka, 1995), hlm 4-13.

${ }^{27}$ Ibid, hlm 34.
} 
yang ethis dan egalitarian terlihat dalam celaannya terhadap disekulibirium ekonomi dan ketidakadilan sosial di dalam masyarakat Makkah pada saat itu. Sebermula sekali al-Qur'an mencela dua aspek yang saling berhubungan erat dalam masyarakat tersebut yaitu politheisme yang merupakan symptom dari segmentasi masyarakat dan ketimpangan sosioekonomi. Al-qur'an terus menecam ketimpangan-ketimpangan ekonomi karena hal inilah yang paling sulit disembuhkan dan yang merupakan iti dari ketimpangan sosial. ${ }^{28}$

Al-Qur'an memerintahkan kaum muslimin untuk memerintahkan kepada kaum Muslimin bahwa mereka lebih baik mengeluarkan harta kekayaan mereka di atas jalan Allah dan dengan demikian mereka brpiutang kepada Allah yang akan dibayar oleh Allah dengan berlipat ganda. Hal ini senada dengan apa yang disampaikan al-Qur'an pada suart Al-Baqarah ayat 261 bahwa bantuan kepada orang miskin bagaikan sebutir biji yang akan tumbuh menjadi tujuh tampuk dan setiap tampuk berisi seratus butir atau lebih. Selain itu, dua beuah kebijaksanaan yang penting yang diambil al-Qur'an adalah melarang riba dan mentapkan zakat. Larangan riba ini bersumber pada ayat :

Kekayaan yang akan engkau ribakan sehingga bertambah dengan kekayaan orang lain itu sesungguhnya tidak akan bertambah menurut pandangan Allah. Tetapi kekayaan yang engkau keluarkan sebagai zakat -yang engkau lakukan dengan tulus hati karena Allah- akan berlipat ganda $(30: 39){ }^{29}$

Sehubungan dengan keadilan yang merata al-Qur'an juga berprinsip bahwa "kekayaan tidak boleh berputar di kalangan orang-orang yang kaya saja" (59:7). Ayat ini menunjukkan sebuah tema yang penting di dalam kebijaksaan ekonomi al-qur'an secara garis besarnya. Dengan demikian setelah di Makkah mencela orang-orang yang menumpuk

${ }^{28}$ Fazlur Rahman, Tema Pokok Al-Qur'an, (Bandung: Pustaka, 1995), hlm 55.

${ }^{29}$ Q.S Ar-Ruum : 39.

Volume 26 Nomor 1 Januari 2015 
kekayaan dan memeras orang miskin, maka di Madinah alQur'an menetapkan zakat. ${ }^{30}$

Pada level sosial-politik al-qur'an ingin menguatkan unit kekeluargaan paling dasar yang terdiri dari orang tua, anakanak, kakek-nenek dan masyarakat Muslim keseluruhan dengan meniadakan rasa kesukuan. Kesetiaan terhadap orang tua ditegaskan dalam ayat $2: 83 ; 4: 36 ; 6: 151 ; 17: 23 ; 29: 8 ; 31: 14$; dan 46: 15. Ikatan kemasyarakatan dapat kita temukan dalam setiap halaman al-Qur'an, terutama sekali di dalam surah yang diturunkan di Madinah. Semua muslim dinyatakan "bersaudara" (49: 10). Bersama-sama mereka tidak dapat digoyahkan "sebagai sebuah bangunan yang kokoh" (6: 14). Pada waktu yang bersamaan al-Qur'an dengan keras melarang peselisihan dan persekongkolan rahasia baik yang dibuat oleh kelompok atau partai politik. Kelompok politik yang dapat bermanfaat itu jangan sampai mengalami degenerasi menjadi kekuatan-kekuatan yang memecahbelahkan masyarakat. Kelompok ini harus saling berkonsultasi dan menghidari bahaya demagogi. ${ }^{31}$

Hal yang merupaan inti dari keseluruhan adalah kesamaan di antara semua ras. Hal ini didukung oleh al-qur'an yang mennghapuskan segala perbedaan di antara manusia kecuali perbedaan karena kebajikan dan taqwa (49: 11-13). AlQur'an menekankan persamaan manusia secara esensil ini dikarenakan di antara mahluk hidup bangsa manusia sajalan yang memiliki keunikan. Ahli-ahli hukum Islam mempunyai alasan yang tepat sekita melandaskan empat macam hak asasi manusia yaitu hak untuk hidup, beragama, mencari nafkah dan memiliki harta kekayaan dan harga diri. Keempat hak ini haru dilindungi oleh negara dan pelanggaran terhadap hak-hak ini termasuk sikap merendahkan manusia karena kemiskinannyamerupakan "perbuatan yang aniaya di muka bumi". Tetapi menurut al-Qur'an "perbuatan yang aniaya di muka bumi" terjadi bersamaan dengan lawan-lawannya yaitu apabila manusi

\footnotetext{
${ }^{30}$ Fazlur Rahman, Tema Pokok Al-Qur'an ...., hlm 60.

${ }^{31}$ Fazlur Rahman, Tema Pokok Al-Qur'an, (Bandung: Pustaka, 1995), hlm 61-64. 
tidak melaksanakan kewajiban-kewajibannya. Kewajiban dan hak adalah hal yang tidak dapat dipisahkan. "Kewajiban tidak dapat bertahan lama tanpa disertai dengan hak, demikian sebaliknya. Sesungguhnya al-Qur'an adalah sebuah dokumen yang menyeru rasa tanggung jawab yang komprehnsif dapat menjamin hak-hak manusia. Sebuah masyarakat yang bertolak dari pemahaman "hak-hak dengan pengertian dibolehkan dan kebebasan dari hukum pasti akan menemui kehancurannya. ${ }^{32}$

Adapun aturan tentang hukum keluarga kususnya di Indonesia mengacu pada Undang-undang perkawinan dan Kompilasi Hukum Islam.Adapaun hukum Islam yang banyak diadopsi dalam positivisasi hukum adalah Kompilasi Hukum Islam. Dalam aturan KHI dapat dikatakan juga mengikuti madzhab hukum Tuhan. Hal ini terlihat pada Pasal $2 \mathrm{KHI}$ tentang definisi perkawinan yang menyebutkan bahwa perkawinan adalah akad yang sangat kuat atau mitsaqan ghalidza untuk menaati perintah Allah dan melaksanakannya ibadah. $^{33}$ Dilanjutkan pula dalam pasal berikutnya bahwa perkawinan dilaksanakan bertujuan untuk membentuk kehudupan rumah tangga yang sakinah, mawaddah dan rahmah. ${ }^{34}$ Adapun dalam UUP perkawinan didefinisikan bahwa perkawinan merupakan ikatan lahir dan bathin antara seorang pria dan wanita sebagai suami istri dengan tujuan membentuk rumah tangga yang bahagia dan kekal berdasarkan Ketuhanan Yang Maha Esa. ${ }^{35}$ Dari kedua definisi tersebut dapat dikatakan KHI masih sangat terpengaruh oleh hukum Tuhan dengan meletakkan nilai ketaatan kepada Allah sekaligus ibadah dalam perkawinan. Selain itu, hakikat dari perkawinan juga masih sangat dipengaruhi oleh bahasa hukum Tuhan yang implikasinya pun juga lebih cenderung pada normatif yang ditetapkan Tuhan.

Tidak hanya dalam perihal hakikat dan definisi perkawinan, terdapat beberapa aturan yang masih menace pada

${ }^{32}$ Ibid, hlm 65-68.

${ }^{33}$ Lihat Pasal 2 Kompilasi Hukum Islam.

${ }^{34}$ Lihat Pasal 3 Kompilasi Hukum Islam.

${ }^{35}$ Lihat Pasal I UU Nomor 1 Tahun 1974 tentang Perkawinan

Volume 26 Nomor 1 Januari 2015 
huum yang ditetapkan oleh Tuhan. Salah satunya adalah mengenai kewarisan yang ditetapkan oleh KHI. Hal yang mendasar yaitu tentang ahli waris, dalam pasal 172 disebutkan bahwa Seseorang dapat dipandang menjadi ahli waris apabila beragama Islam yang diketahui dari Kartu Identitas atau pengakuan. Hal ini terlihat masih sangat mengadopsi ajaran yang dirumuskan dalam normative Tuhan. Memang banyak yang beselisih pendapat mengenai hal ini, akan tetapi dengan meliaht konteks historis dan problemtika kontemporer saat ini hendaknya perbedaan agama tidak menjadi penghalang dalam kewarisan. Perbedaan agama haruslah dimaknai kembali sesuai dengan semangat kemaslahatan umat.

Selain itu, mengenai pembagian harta warisan juga masih dapat dikatakan mengacu pada hukum Tuhan. Bagian harta waris yang dibagikan diatur dalam Kompilasi Hukum Islam (KHI) pada Buku II BAB III, mulai dari pasal 176 sampai dengan pasal 191. Masalah kewarisan Islam dengan tegas menyatakan bahwa seorang pria mendapat sama dengan dua orang perempuan. Hal ini pula yang diadopsi oleh KHI dalam menentukan bagian waris bagi laki-laki dan perempuan. Dari pasal pasal tersebut, kesemuanya menjelaskan bahwa harta warisan yang diperoleh oleh seorang ahli waris laki-laki sama dengan bagian dua harta waris bagi wahli waris perempuan.

Jika sejenak melihat historis pembagian dua banding satu ini dapat kita telusuri, pada waktu dulu kaum wanita sebelum terbitnya matahari Islam tidak diberi warisan sama sekali, dengan alasan perempuan tidak bisa berperang dan tidak mampu mempertahankan kabilah. Keadaan rasa keadilan pada sebagian tempat teryata "berubah" perempuan dianggap mempunyai hak yang sama dengan kaum laki-laki setidaktidaknya dalam hal memperoleh bagian dalam harta peninggalan ibu bapaknya. Maka dari itu, hendaknya KHI pun juga ikut mendorong terwujudnya tujuan hukum yaitu ketertiban sosial yang diartikan menciptakan rasa damai dan aman secara kolektif. Keadaan adil dan aman yang tidak hanya dirasakan oleh satu pihak, pihak laki-laki misalnya, tetapi juga bagi perempuan. 
Menurut penulis, mazhab hukum Islam lebih mengacu pada hukum alam yang berprinsip bahwa segala hukum adalah bersumber dari norma Tuhan. Islam menjadikan al-Qur'an pedoman utama dalam mengatur segala kehidupan manusia di bumi. Meskipun hukum Islam telah diupayaan untuk dipositivisasikan, namun dalam ranah hukum keluarga khususnya, masyarakat Muslim masih belum berani meninggalkan atau dengan kata lain menginterpretasi ulang norma-norma yang ditentukan oleh Tuhan untuk disesuaikan dengan kondisi masyarakat saat ini, Hal ini tentu saja dipengaruhi oleh adanya nilai-nilai ketaatan dan ibadah yang harus dilakukan oleh masyarakat Muslim sebagai kewajibannya kepada Sang Pencipta, Tuhan Yang Maha Esa.

\section{Kesimpulan}

Filsafat Hukum adalah cabang dari filsafat yang mempelajari hukum yang benar, atau dapat juga kita katakan Filsafat Hukum adalah merupakan pembahasan secara filosofis tentang hukum, yang sering juga diistilahkan lain dengan Jurisprudence, adalah ilmu yang mempelajari hukum secara filosofis, yang objeknya dikaji secara mendalam sampai pada inti atau dasarnya, yang disebut hakikat. Terdapat enam macam aliran dalam filsafat hukum, meliputi; mazhab hukum alam; mazhab positivisme hukum; hukum murni; mazhab sejarah; mazhab sociological jurisprudence; dan realisme hukum.

Dari sekian mazhab yang telah dijelaskan dapat dikatakan bahwa masing-masing mazhab memiliki kelebihan dan kekurangan masing-masing, namun terlepas dari semua itu setiap mazhab mengedepankan apa yang menjadi kebutuhan masyarakat yaitu, ketertiban sosial. Tidak semata-mata sebuah idealisme tetapi juga ide-ide tentang hukum dan moral yang saling berkaitan. ${ }^{36}$

36 John Kelsay dan Summer B. Twiss, Agama dan Hak Asasi Manusia, terj. Ahmad Suaedy dan Elga Serapung, cet ke-2, (Yogyakarta: Institute Dian/ Interfidei, 2007), hlm 125. 


\section{DAFTAR PUSTAKA}

Ali, Zainuddin, Filsafat Hukum, Jakarta: Sinar Grafika, 2006.

Djamil, Fathurrahman, Filsafat Hukum Islam, Jakarta: Logos Wacana Ilmu, 1997.

Ghofur Anshori, Abdul Filsafat Hukum, Yogyaarta: Gajah Mada University Press, 2009.

Prasetyo, Teguh dan Barkatullah, Abdul Halim., Ilmu Hukum dan Filsafat Hukum, Yogyakarta: Pustaka Pelajar, 2011.

Rahman, Fazlur, Tema Pokok Al-Qur'an, alih bahasa Anas Mahyuddin, Bandung: Pustaka, 1995.

Rasyidi, Lili Filsafat Hukum, Mazhab dan Refleksinya, Bandung: Remaja Rosdakarya, 1994.

Salman, Otje, Filsafat Hukum: Perkembangan dan Dinamika Masalah, (Bandung :Refika Aditama), 2010.

Syauqi, Ahmad, Aliran-Aliran Dalam Filsafat Hukum Dan Yang Relevan Dengan Suasana Kebangsaan Indonesia, pdf.

Undang-unang Nomor 1 Tahun 1974. 